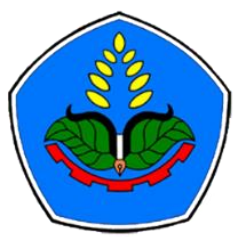

AGROPROSS

National Conference

Proceedings of Agriculture

\section{Proceedings: \\ Peran Teaching Factory Di Perguruan Tinggi Vokasi Dalam \\ Mendukung Ketahanan Pangan Pada Era New Normal}

Tempat : Politeknik Negeri Jember

Tanggal : 8-9 Juli 2020

\section{Publisher:}

Agropross, National Conference Proceedings of Agriculture

ISBN : 978-623-94036-6-9

DOI : 10.25047/agropross.2020.42

\title{
Pengaruh Inokulasi Rhizobium spp terhadap Pertumbuhan dan Hasil Produksi Kacang Tanah pada Cekaman Kekeringan
}

\author{
Author(s): Ifroh Hatun Hasanah ${ }^{(1) *}$; Iqbal Erdiansyah ${ }^{(1)}$ \\ (1) Program Studi Teknologi Produksi Tanaman Pangan, Jurusan Produksi Pertanian, Politeknik Negeri Jember \\ * Corresponding author: ifroh04@gmail.com
}

\begin{abstract}
Bondowoso is one of the cities in East Java, has a rainfed, field and forest area. The agricultural sector is the leading sector. Peanut is one of the cultivated plants. Peanut production in Bondowoso has decreased. One of the reasons for the decline in peanut production is that there is a lack of water for the growth process of plants, which has an effect on peanut production. One technology that can be used is irrigation engineering on rainfed land, besides irrigation engineering there is a need for fertilization using Rhizobium spp. The application of Rhizobium spp inoculum with treatments of watering once in 2 days (P1), 4 days (P2), 6 days (P3) and 8 days (P4). The experiment results revealed that applying Rhizobium spp on peanut plant with drought stress had an effect on the growth and production of peanut. Rhizobium spp affected to increase plant height, wet pod weight, dry pod weight, dry seed weight, root nodule weight. Rhizobium spp could fix free nitrogen in the air under drought stress condition. Rhizobium could provide nutrients for plant in the form of NO 3-. The plant used NO 3 -for photosynthesis and producing products in the form of proteins. The best treatment was watering once in 2 days and adding Rhizobium spp with a concentration of $20 \mathrm{ml} / \mathrm{l}$.
\end{abstract}

Keyword:

Drought Stress;

Fixation

Nitrogen;

Rhizobium spp.;

\section{Kata Kunci:}

Cekaman

Kekeringan;

Fiksasi

Nitrogen;

Rhizobium spp;

\begin{abstract}
ABSTRAK
Bondowoso merupakan salah satu kota di Jawa Timur, memiliki kawasan budidaya tadah hujan, sawah dan hutan. Sektor pertanian merupakan sektor unggulan.Kacang tanah merupakan salah satu tanaman yang dibudidayakan.produksi kacang tanah di Bondowoso mengalami penurunan. Penurunan produksi kacang tanah salah satunya dapat disebabkan oleh kekurangan air untuk proses pertumbuhan tanaman sehingga berpengaruh terhadap produksi kacang tanah. Teknologi yang bisa digunakan salah satunya adalah rekayasa irigasi pada lahan tadah hujan, selain rekayasa irigasi perlu adanya rekayasa pemupukan dengan menggunakan Rhizobium spp. Aplikasi inokulumRhizobium spp dengan perlakuan dengan waktu penyiraman 2 hari sekali $(\mathrm{P} 1), 4$ hari sekali (P2), 6 hari sekali (P3) dan 8 hari sekali (P4). Hasil percobaan aplikasi Rhizobium spp pada tanaman kacang tanah dengan cekaman kekeringan memberikan efek terhadap pertumbuhan dan produksi kacang tanah. Pengaruh aplikasi Rhizobium spp meningkatkan tinggi tanaman, berat polong basah, berat polong kering, berat biji kering, berat bintil akar.Rhizobium spp dapat memfiksasi nitrogen bebas di udara pada kondisi cekaman kekeringan.Rhizobium dapat menyediakan hara bagi tanaman dalam bentuk $\mathrm{NO}_{3}^{-}$, tumbuhan menggunakan $\mathrm{NO}_{3}{ }^{-}$untuk fotosintesis dan hasil produk berupa protein.Perlakuan terbaik yaitu penyiraman 2 hari sekali dan penambahan Rhizobium spp dengan konsentrasi $20 \mathrm{ml} / 1$.
\end{abstract}




\section{PENDAHULUAN}

Bondowoso merupakan salah satu kota yang berada di Jawa Timur. Bondowoso memiliki kawasan budidaya tadah hujan, sawah dan hutan. Sektor pertanian menjadi sektor unggulan dan memiliki potensi untuk dikembangkan.Kacang tanah merupakan salah satu komoditas yang dibudidayakan oleh masyarakat setempat. Berdasarkan data BPS produksi kacang tanah di Bondowoso mengalami penurunan sebanyak $20 \%$, yaitu pada tahun 2016 produksi kacang tanah sebesar 103 ton dan pada tahun 2017 sebesar 82 ton.

Penurunan produksi kacang tanah salah satunya dapat disebabkan oleh kekurangan air untuk proses pertumbuhan tanaman sehingga berpengaruh terhadap produksi kacang tanah. Kekurangan air terjadi ketika memasuki musim kemarau, selain musim kemarau kekurangan air untuk pertumbuhan tanaman dapat terjadi pada lahan-lahan tadah hujah.

Lahan tadah hujan banyak dijumpai di Bondowoso, lahan tadah hujan ini dapat digunakan untuk mengoptimalkan hasil produksi kacang tanah. Penggunaan lahan tadah hujan tersebut perlu adanya teknologi.Teknologi yang bisa digunakan salah satunya adalah rekayasa irigasi pada lahan tadah hujan, selain rekayasa irigasi perlu adanya rekayasa pemupukan yang menopang terhadap pertumbuhan dan produksi kacang tanah pada lahan tadah hujan.Pemanfaatan teknologi irigasi dan aplikasi Rhizobium spp sebagai bio fertilizer dalam budidaya kacang tanah bisa digunakan untuk mengoptimalkan produksi kacang tanah.

\section{BAHAN DAN METODE}

Penelitian ini dilaksanakan pada bulan September-Desember 2019 menggunakan screen house, di Desa Sumber Sari, Kecamatan Maesan, Bondowoso dengan ketinggian tempat 280 mdpl. Koordinat wilayah antara $113^{\circ} 48^{\prime} 10^{\prime \prime}-113^{\circ} 48^{\prime} 26^{\prime \prime}$ BT dan $7^{\circ} 50^{\prime} 10^{\prime \prime}$ $-7^{\circ} 56^{\prime} 41^{\prime \prime}$ LS. Suhu udara antara $20,4^{\circ} \mathrm{C}-$ $25,9^{0} \mathrm{C}$.

Bahan yang digunakan yaitu, Kacang varietas Hypoma1, pupuk urea, SP-36, KCL, Rhizobium spp, insektisida, polybag. Rancangan percobaan yang digunakan adalah RAK faktorial, faktor pertama yaitu waktu penyiraman dan faktor kedua adalang aplikasi rhizobium.Pengumpulan data secara kuantitatif. Data kuantitatif selanjutnya dilakukan dengan sidik ragam dan uji lanjut DMRT.

Inokulasi Rhizobium spp pada tanaman kacang tanah dimulai dari persiapan media tanam untuk budidaya tanaman kacang tanah yaitu, mengambil tanah kemudian dihancurkan jika berbentuk bongkahan, kemudian dicampur dengan pupuk dasar yaitu pupuk kandang sapi. Selanjutnya bagi tanah kedalam polybag dengan ukuran polybag $40 \mathrm{~cm}$ x 20 $\mathrm{cm}$, tiap polybag sebanyak $7 \mathrm{~kg}$ tanah.Menata semua polybag yang telah terisi oleh media tanam sesuai dengan layout penelitian. Penyiraman dilakukan sesuai dengan perlakuan, perlakuan cekaman kekeringan yaitu, 2 hari sekali, 4 hari sekali, 6 hari sekali dan 8 hari sekali dilakukan dari umur 16 HST- 60 HST. Pemupukan dilakukan sesuai perlakuan yaitu dengan konsentrasi $0 \mathrm{ml} / 1$ dan $20 \mathrm{ml} / 1$ dengan waktu aplikasi 8 hari sekali. Proses budidaya yang lainnya sesuai dengan standart operasional pelaksanaan budidaya kacang tanah.

Parameter yang diamati diantaranya, suhu udara, kelembapan udara, kadar air, tinggi tanaman, berat polong kering, berat biji kering dan jumlah bintil akar.

Data kuantitatif yang telah didapat selanjutnya dianalisis menggunakan ANOVA dan dilakukan uji lanjut apabila terdapat interaksi dengan menggunakan uji DMRT.

Berdasarkan parameter yang telah diamati didapatkan hasil percobaan 
aplikasi Rhizobium spp pada tanaman kacang tanah dengan cekaman kekeringan memberikan efek terhadap pertumbuhan dan produksi kacang tanah. Pengaruh aplikasi Rhizobium spp meningkatkan tinggi tanaman, berat polong basah, berat polong kering, berat biji kering, berat bintil akar.Rhizobium spp dapat memfiksasi nitrogen bebas di udara pada kondisi cekaman kekeringan.Rhizobium dapat menyediakan hara bagi tanaman dalam bentuk $\mathrm{NO}_{3}^{-}$, tumbuhan menggunakan $\mathrm{NO}_{3}{ }^{-}$untuk fotosintesis dan hasil produk berupa protein.Perlakuan terbaik yaitu penyiraman 2 hari sekali dan penambahan Rhizobium spp dengan konsentrasi $20 \mathrm{ml} / 1$.

Analisa data secara kuantitatif dengan menggunakan ANOVA dan dilakukan uji lanjut apabila terdapat interaksi dengan menggunakan uji DMRT.

\section{HASIL DAN PEMBAHASAN}

Hasil pengamatan suhu udara, kelembapan udara, suhu tanah dan kadar air pada penelitian yang dilakukan di Desa Sumber Sari, Kecamatan Maesan, Kabupaten Bondowoso pada tabel di bawah.

Pengujian Suhu Udara, Kelembapan Udara, dan Suhu Tanah pada lingkungan sekitar tempat penelitian dilaksanakan.

Tabel 1 Hasil Pengujian Suhu Udara dan Kelembapan Udara

\begin{tabular}{llc}
$\begin{array}{c}\text { Pengujian } \\
\text { Hari -ke }\end{array}$ & $\begin{array}{c}\text { Suhu } \\
\text { Udara } \\
\left({ }^{\mathrm{O}} \mathrm{C}\right)\end{array}$ & $\begin{array}{c}\text { Kelembapan } \\
\text { Udara(\%) }\end{array}$ \\
\hline 15 & 34,20 & 55,33 \\
35 & 33,72 & 55,30 \\
55 & 33,70 & 56,00 \\
\hline Rerata & 33,87 & 55,53 \\
\hline
\end{tabular}

Hasil pengamatan pertumbuhan dan produksi kacang tanah dengan variabel tinggi tanaman pada umur $25 \mathrm{HST}$, berat polong basah, berat polong kering, berat biji kering, jumlah bintil akar dan berat bintil akar kacang tanah.
Tabel 2 Kadar Air Tanah Pada Media Tanam Kacang Tanah

\begin{tabular}{ll}
\hline Perlakuan & Kadar Air \\
\hline P1 & $50,94 \%$ \\
P2 & $30,96 \%$ \\
P3 & $19,54 \%$ \\
P4 & $14,59 \%$ \\
\hline
\end{tabular}

Tinggi Tanaman Kacang Tanah

Tabel 3. Uji Lajut DMRT 5\% Perlakuan P (Tinggi Tanaman Umur 25 HST)

\begin{tabular}{ccc}
\hline Perlakuan & Rerata & Notasi \\
\hline P1 & 72,50 & $\mathrm{a}$ \\
P2 & 52,25 & $\mathrm{~b}$ \\
P4 & 44,00 & $\mathrm{c}$ \\
P3 & 42,50 & $\mathrm{c}$
\end{tabular}

Keterangan: Notasi yang diikuti dengan huruf yang sama berbeda tidak nyata pada DMRT taraf 5\%, notasi yang diikuti huruf berbeda artinya berbeda nyata

Berdasarkan uji lanjut DMRT 5\% perlakuan waktu penyiraman pada Tabel 1.3menunjukkan perlakuan paling baik yaitu pada penyiraman 2 hari sekali dengan rata-rata tinggi tanaman $72,50 \mathrm{~cm}$ kemudian disusul penyiraman 4 hari sekali dengan tinggi $52,25 \mathrm{~cm}$. Dari data tersebut tanaman dengan waktu penyiraman lebih lama memiliki tinggi tanaman yang lebih rendah. Air merupakan komponen tanaman yang paling utama sebagai penyusun sel tanaman serta air juga berfungsi untuk media reaksi pada seluruh metabolisme tanaman (Hanafiah, A, 2014)

Kekurangan air dapat menyebabkan tekanan turgor menurun sehingga menghambat pertumbuhan tanaman baik secara fisiologi dan biokimia. Penurunan tinggi pada tanaman yang waktu penyiramannya lebih lama sesuai dengan penelitian Henom (2017) yang mana hasil percobaannya menunjukan tanaman yang tercekam kekeringan memiliki ukuran yang lebih pendek dibandingkan dengan tanaman yang tidak dicekam kekeringan. 
Cekaman kekeringan pada fase vegetatif dapat menurunkan tinggi tanaman, selain itu dapat menurunkan produksi, menurunkan indeks luas daun serta mengubah morfologi batang menjadi lebih pendek,selain itu tanaman yang kekurangan pasokan air dapat menyebabkan kematian pada tanaman (Pratiwi, 2013).
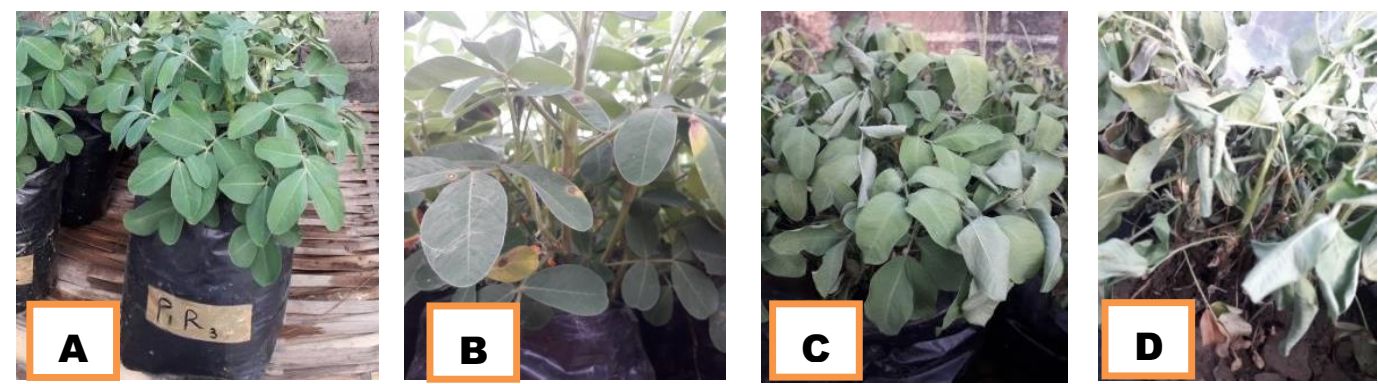

Gambar 1 Penampakan Morfologi Kacang Tanah Akibat Kekeringan A : Penyiraman 2 Hari Sekali; B : 4 Hari Sekali; C : 6 Hari Sekali; D : 8 Hari Sekali

Berdasarkan hasil pengujian kadar air tanah didapatkan hasil bahwa dengan waktu penyiraman 8 hari sehali menghasilkan kadar air terendah yaitu $14,59 \%$. Sedangkan perlakuan dengan waktu penyiraman 2 hari sekali didapatkan kadar air 50,94 \%. Kadar air yang rendah dapat menyebabkan tanaman layu dan terdapat batang yang mati seperti terdapat pada Gambar 1 D. Selain karena kadar air tanah yang rendah menyebabkan beberapa batang pada tanaman kacang tanah mengering hal lain yang mendukung terjadinya pengeringan batang pada kacang tanah disebabkan karena suhu udara yang terlalut tinggi dan kelembapan udara yang terlalu rendah sehingga tidak sesuai dengan syarat tumbuh kacang tanah.

Pada tabel hasil pengujian dapat dilihat bahwa suhu udara pada saat budidaya kacang tanah sebesar $33,87^{\circ} \mathrm{C}$, dengan kelembapan udara $55,53 \%$ dan. Syarat tumbuh kacang tanah membutuhkan suhu panas yaitu berkisar antara $28{ }^{\circ} \mathrm{C}$ $32^{\circ} \mathrm{C}$, dan kelembapan udara lumayan lembab yaitu 65\%-75\% (Rukmana, 1998).

Rata-rata tinggi tanaman yang diberi tambahan dengan Rhizobium spp yaitu 57 $\mathrm{cm}$, sedangkan tanaman yang tidak diberi penambahan Rhizobium spp 48,625 $\mathrm{cm}$.Seperti kita ketahui pada umumnya
Rhizobium spp ini mampu meningkatkan penyerapan nitrogen bebas yang ada di atmosfer yang nantinya dapat digunakan oleh tanaman. Nitrogen memiliki peranan penting untuk metabolisme seluler khususnya untuk pembelahan sel,apabila kandungan nitrogennya semakin menurun maka kemampuan bakteri membelah menjadi semakin menurun pula. Akibatnya pertumbuhan bakteri pun menjadi rendah( Gunawandkk, 2010).

Tabel 4. Uji Lanjut DMRT 5\% Perlakuan A (Tinggi Tanaman Umur 25)

\begin{tabular}{ccc}
\hline Perlakuan & Rerata & Notasi \\
\hline A1 & 57,00 & $\mathrm{a}$ \\
A2 & 48,62 & $\mathrm{~b}$ \\
\hline
\end{tabular}

Keterangan: Notasi yang diikuti dengan huruf yang sama berbeda tidak nyata pada DMRT taraf 5\%, notasi yang diikuti huruf berbeda artinya berbeda nyata.

Nitrogen bebas yang yang ada di atmosfer tidak serta merta langsung bisa digunakan oleh tanaman melainkan pemanfaatannya dilakukan lewat bantuan Rhizobium spp, yang mana nitrogen bebas ini akan diubah oleh Rhizobium spp menjadiamonium dan selanjutnya akan ternitrifikasi menjadi nitrit sehingga bisa digunakan oleh tanaman kacang tanah. 
Data diatas dapat dilihat bawa penambahan Rhizobium spp mampu memberikan pengaruh tinggi kacang tanah dibandingkan dengan perlakuan tanpa Rhizobium spp. Nitrogen memiliki peran secara keseluruhan pertumbuhan tanaman, baik batang, cabang, dan daun selain itu nitrogen sebagaipenyusun protein, klorofil, asam nukleat dan berperan penting dalam pertukaran koenzim.Rhizobium spp menginfeksi tanaman kacang tanah melalui rambut akarnya yang halus membentuk benang-benang yang selanjutnya memasuki sel korteks. Bakteri ini posisinya berada di dalam sitoplasma, yang selanjutnya menstimulasi sehingga sel membelah dan membengkak, maka terbentuklah yang mananya bintil akar. didalam bintil akar inilah bakteri Rhizobium sppmemfiksasi Nitrogen bebas, yang mana dalam fiksasi $\mathrm{N}$ ini melibatkan enzim nitrogenase (Hanafiah, 2014).

Proses saling menguntungkan ini tidak akan terjadi apabila Rhizobium spptidak mendapatkan makanan dari tanaman inang. Simbiosis menguntungkan ini terjadi karena tanaman legum mengeluarkan asam amino dan amidaamida dari dalam tanaman kacang tanah, selain itu pula adanya karbohidrat dalam tanah. (Sutedjo, 1996).

Cekaman kekeringan dapat menghambat pertumbuhan tanaman, namun ketika tanaman sudah kembali mendapatkan air, tanaman akan kembali melanjutkan perkembangannya pada fase berbunga jika tanaman mengalami kekurangan air maka dapat menyebabkan berkurangnya bunga yang terbentuk serta dapat pula menunda proses pembungaan, hal seperti itu dikarenakan proses fotosintesis terhambat karena stomata tertutup akibat kekurangan air selain itu cekaman air juga dapat menurunkan turgor, yang mana turgor sangat berperan dalam menentukan perkembangan tanaman, perbanyakan sel, membuka serta menutupnya stomata, perkembangan daun, bunga, struktur serta aktifitas dari enzim dipengaruhi oleh air dalam tanaman. Pada fase generatif khusunya pada saat kacang tanah memasuki masa tumbuhnya ginofor jika kekurangan air dapat menyebabkan ginofor tidak berkembang menjadi polong serta proses pengisian biji terhambat (Pratiwi, 2013).

\section{Berat Polong Basah dan berat polong kering Kacang Tanah}

Tabel 5. Uji DMRT 5\% Perlakuan Inokulasi Rhizobium spp Berat Kering dan Berat Basah Polong

\begin{tabular}{llll}
\hline No & Variabel & Rerata & Notasi \\
\hline 1 & Berat & 314,338 & $\mathrm{a}$ \\
\cline { 2 - 4 } & polong & 274,428 & $\mathrm{~b}$ \\
& basah A1 & & \\
& Berat & & \\
& polong & & \\
basah A2 & & \\
\hline 2 & Berat & 143,58 & $\mathrm{a}$ \\
\cline { 2 - 3 } & kering \\
& kering A1 & 125,53 & $\mathrm{~b}$ \\
& $\begin{array}{l}\text { Berat } \\
\text { kering } \\
\end{array}$ & & \\
kering A2 & & \\
\hline
\end{tabular}

Perlakuan Inokulasi Rhizobium pada variabel berat polong basah diatas menunjukkan perlakuan yang paling baik yaitu pada perlakuan dengan penambahan Rhizobium berat polong basah dengan menghasilkan berat rata-rata 314,3 gr, sedangkan berat polong kering dengan penambahan Rhizobium didapatkan berat rata-rata tertinggi yaitu $143,58 \mathrm{gr}$, ini lebih tinggi dibandingkan dengan perlakuan tanpa Rhizobium. Rhizobium mampu menambat Nitrogen bebas yang selanjutnya diubah menjadi protein yang digunakan oleh kacang tanah untuk keperluan pertumbuhan dan hasil produk kacang tanah (Henom,2017).

\section{Jumlah Bintil Akar}

Berdasarkan hasil uji lanjut DMRT

$5 \%$ interaksi perlakuan waktu 
penyiramandan inokulasi Rhizobium didapatkan hasil kombinasi perlakuan terbaik yaitu pada perlakuan P1A1 dengan rata-rata jumlah bintil akar 536, perlakuan P1A1 ini merupakan perlakuan cekaman kekeringan dengan waktu penyiraman 2 hari sekali dengan penambahan Rhizobium. Waktu penyiraman 2 hari tanah masih basah dan tidak pula kering, tanah masih lembab karena sisa air selama 2 hari. Bakteri menyukai tempat yang lembab untuk proses pembelahan sel setelah menginfeksi akar tanaman. Faktor yang mempengaruhi fiksasi salah satunya adalah ketersediaan air (Sari,2015).

Tabel 1.6 UjiDMRT $5 \%$ Interaksi $(\mathrm{P} \times \mathrm{A})$ Berat Bintil Akar

\begin{tabular}{lcl}
\hline Perlakuan & Rerata & Notasi \\
\hline P1A1 & 536 & $\mathrm{a}$ \\
P2A1 & 443 & $\mathrm{~b}$ \\
P3A1 & 379 & $\mathrm{~b}$ \\
P1A2 & 355 & $\mathrm{~b}$ \\
P2A2 & 348 & $\mathrm{~b}$ \\
P3A2 & 338 & $\mathrm{~b}$ \\
P4A1 & 337 & $\mathrm{~b}$ \\
P4A2 & 310 & $\mathrm{~b}$ \\
\hline
\end{tabular}

Keterangan: Notasi yang diikuti dengan huruf yang sama berbeda tidak nyata pada DMRT taraf $5 \%$, notasi yang diikuti huruf berbeda artinya berbeda nyata

Ketersediaan air yang kurang untuk tanaman kacang tanah dapat pula menurunkan populasi Rhizobium spp didalam tanah, dengan demikian semakin sedikit pula Rhizobium spp didalam tanah mengineksi akar yang biasanya ditandai dengan adanya benjolan atau sering disebut dengan bintil akar. Sebagai akibatnya tanah yang kering jumlah Rhizobium juga menurun dengan cepat (Sutedjo, 1996).

Ketersedian air yang banyak sangat dibutuhkan oleh tanaman untuk proses fotosintesis, tanaman yang kekurangan air maka proses fotosintesis akan menurun, sehingga hasil fotosintat untuk disebarkan keseluruh tanaman juga akan menurun, maka dapat dikatakan Rhizobium spp akan mendapat makanan dari tanaman inang semakin sedikit. Sedikitnya makanan yang didapatkan oleh Rhizobium spp juga akan berpengaruh terhadap proses penambatan nitrogen bebas yang ada di atmosfer. Sebagai salah satu bukti yaitu jumlah bintil dan berat akar juga semakin sedikit. Penampang akar dengan aplikasi Rhizobiumspp dan tanpa Rhizobium spp dapat di lihat pada gambar dibawah:

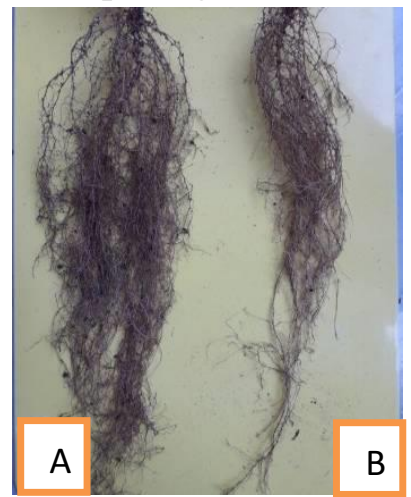

Gambar 1.2 Penampang Akar Kacang

Tanah A : Penampang Akar Kacang

Tanah Dengan Penambahan Rhizobium

\section{B : Penampang Akar Kacang Tanah}

Tanpa Penambahan Rhizobium

Bintil akar ini ada 2 tipe yaitu yang aktif dan yang tidak akti. Bintil akar yang aktif didalamnya memiliki warna merah muda jika dipecah, hal ini karena Rhizobium spp memiliki pigmen warna yaitu leghaemoglobin, sedangkan untuk bintil akar yang tidak aktif ditandai dengan warna hitam dan bintil kopong, selain itu bintil sangat kecil dan berisi sedikit bakteroid, biasanya merupakan akumulai tepung yang berada dalam sel tanaman inang (Sari, 2015).

\section{KESIMPULAN}

Aplikasi inokulumRhizobium spp meningkatkan produksi berat polong basah dan tinggi tanaman, serta berat biji kering. Interaksi waktu penyiraman dan aplikasi Rhizobium spp berpengaruh terhadap jumlah bintil akar. 


\section{DAFTAR PUSTAKA}

Fallah, A. F. (2009).PerspektifPertanian dalam Lingkungan yang Terkontrol. susunan redaksi, 81.http://io.ppi.jepang.org.

Gunawan, R., Anas, I., Hazra, F. (2010). Produksi

MasalInokulumAzotobacter, Azospirillum dan Bakteri Pelarut Fosfat dengan Menggunakan Media Alternatif. Jurnal Ilmu Tanah dan Lingkungan, 12(2), 33-39.

http://journal.ipb.ac.id/index.php/jta nah/article/view/16600

Hanafiah, A, K. (2014).Dasar Dasar Ilmu Tanah. KANISUS (Anggota IKAPI).

Hemon, A. F. (2017). Pertumbuhan dan Hasil Kacang Tanah yang Diberi Rhizobium pada Cekaman Kekeringan. Agroteksos: Agronomi Teknologi Dan Sosial Ekonomi Pertanian, 25(1), 1-10.

https://agroteksos.unram.ac.id/index .php/Agroteksos/article/view/48

Pratiwi, H.(2013). Pengaruh Kekeringan pada Berbagai Fase Tumbuh Kacang Tanah. Buletin Palawija, (22), 71-78 http://ejurnal.litbang.pertanian.go.id/ index.php/bulpa/article/view/1296

Pusat Statistik. Provinsi Jawa Timur. Luas Panen, Produktivitas, dan Produksi Komoditi Kacang Tanah di Jawa Timur, 2002-

2017.https://jatim.bps.go.id/

Rukmana, R. 1998. Kacang Tanah. KANISUS (Anggota IKAPI).

Sari, R.,Prayudyaningsih, R. (2015). Rhizobium: pemanfaatannya sebagai bakteri penambat nitrogen. Info Teknis EBONI, 2(1), 51-56. http://ejournal.forda-

mof.org/ejournal-

litbang/index.php/buleboni/article/vi ew/5054.

Sotedjo. 1996. Mikro Biologi Tanah. Anggota IKAPI DKI Jakarta. 